\title{
Immunomodulatory effects of $\beta-1,3 / 1,6$-glucan and lactic acid bacteria in LP-BM5 murine leukemia viruses-induced murine acquired immune deficiency syndrome
}

\author{
Min-Soo Kim ${ }^{1}$, JoongSu Kim${ }^{1}$, Min Jung Ryu ${ }^{2}$, Ki hong Kim³ ${ }^{3}$ Kwontack Hwang* \\ ${ }^{1}$ Microbial Biotechnology Research Center, Korea Research Institute of Bioscience and Biotechnology (KRIBB), \\ Jeongeup 56212, Korea \\ ${ }^{2}$ Department of Cosmetology science, Nambu University, Gwangju 62271, Korea \\ ${ }^{3}$ Jeonnam Institute for Regional Program Evaluation, Jangseong 57248, Korea \\ ${ }^{4}$ Department of Food and Nutrition, Nambu University, Gwangju 62271, Korea
}

\section{면역결핍 모델에서 $\beta$-1,3/1,6-glucan과 유산균을 이용한 in vivo 면역 활성 조절 효과}

\author{
김민수 ${ }^{1} \cdot$ 김중수 $^{1} \cdot$ 류민정 ${ }^{2} \cdot$ 김기홍 $^{3} \cdot$ 황권 택 $^{4 *}$ \\ 1한국생명공학연구원 미생물기능연구센터, ${ }^{2}$ 남부대학교 향장미용학과, \\ ${ }^{3}($ 재 $)$ 전남지역사업평가단, ${ }^{4}$ 남부대학교 식품영양학과
}

\begin{abstract}
In this study, $\beta-1,3 / 1,6-$ glucan, lactic acid bacteria, and $\beta-1,3 / 1,6$-glucan+lactic acid bacteria were tested for 10 weeks using an immunodeficient animal model infected with LP-BM5 murine AIDS virus On the immune activity. Cytokines production, plasma immunoglobulin concentration, $T$ cell and $B$ cell proliferation were measured. As a result, the T cell proliferative capacity which was weakened by immunization with LP-BM5 murine AIDS virus increased significantly $\mathbf{T}$ cell proliferative capacity compared with the red ginseng control group. B cell proliferative capacity was significantly higher than the infected control group. Increased B cell proliferation was reduced. In the cytokine production, IL-2, IL-12 and IL-15 in the Th1-type cytokine increased the secretion of IL-2, IL-12 and IL-15 compared to the infected control. The proliferative capacity of the treated group was higher than that of the mixed treatment group. TNF- $a$ was significantly decreased compared with the infected control group. The IL-4, IL-6 and IL-10 levels were significantly inhibited in the infected control group and the Th1/Th2 type cytokine expression was regulated by immunohistochemistry. IgE, IgA, and IgG levels were significantly lower in the immunoglobulin secretion assay than in the control. As a result, the immunomodulatory effect of $\beta-1,3 / 1,6$-glucan+lactic acid bacteria was confirmed by mixing with LP-BM5 murine AIDS virus-infected immunodeficient animal model.
\end{abstract}

Key words : $\beta-1,3 / 1,6$-glucan, lactic acid bacteria, immunomodulatory effect, in vivo, cytokines

\section{서 론}

*Corresponding author. E-mail : hwangskt@nambu.ac.kr Phone : 82-62-970-0174, Fax : 82-62-970-0174

Received 18 September 2017; Revised 21 November 2018; Accepted 20 December 2017.

Copyright (c) The Korean Society of Food Preservation. All rights reserved.
면역 체계는 외부의 다양한 해로운 물질과 알레르겐, 감 염원 등으로부터 인체를 보호하는 방어체계로서 질병의 발생을 억제시키는 역할을 하며, 면역 억제와 증진의 작용 으로 항상성을 유지하여 면역을 조절하게 된다. 면역 기능 이 결핍되거나 저하된 상태에서는 면역 반응이 제대로 활성 화 되지 못하고 체내의 이물질에 대한 반응을 제대로 못하 여 감염을 일으키게 되며, 반대로 일부의 면역 반응이 과하 게 반응하면 면역 체계가 불균형을 이루어 결과적으로 자가 
면역질환, 알레르기 반응 등을 일으키게 된다. 따라서 인체 의 면역 반응은 균형을 이루어 조절이 정상적으로 되어야 건강함을 유지할 수 있다. 면역기능에 영향을 미치는 요인 으로는 유전적 요인 및 환경적 요인, 노화, 성별, 육체적 및 심리적 스트레스, 영양상태, 식이습관, 질병 등이 있다 $(1,2)$. 이러한 요인에 의하여 체내 면역 세포 활성이 감소되 거나 면역계 불균형이 일어나 질환을 유발시키는데 노화는 면역반응에 있어 아주 중요하고 다양한 변화를 가져온다. $\mathrm{Th} 1$ 세포 활성 $\mathrm{IgG}, \mathrm{IgA}$ 등의 항체생성 능력은 감소하게 되며, 이러한 변화는 호르몬의 변화, 항원 노출의 축적 등 때문으로 추정되며, 세포성 면역의 감소로 이어진다. 극심 한 영양결핍은 다양한 면역세포에 영향을 주고, 보체의 활성이 감소되고 대식세포의 탐식작용이 감소될 뿐만 아니 라 항체 생성능력도 저하되게 된다(3).

“면역증강”이란 면역기능이 내부 또는 외부의 요인에 의해 저하된 상태를 정상적인 면역 기능을 유지할 수 있는 수준으로 증진시킨다는 의미이며, 면역기능증강 건강기능 식품이란 광범위하게는 면역반응의 이상을 정상화하는데 도움을 줄 수 있는 기능을 나타내는 식품이라고 정의할 수 있다. 하지만, 보다 직접적으로 저하된 면역기능을 증강 시킬 수 있는 식품을 의미하고, 정상 면역기능을 증진시키 는 경우도 포함한다. 국내 소비자들은 면역능력과 관련하 여 면역력증가(37.8\%), 감기예방(24.3\%), 질병예방(15.3\%) 등 기대효과를 건강기능식품에서 예상하고 있는 것으로 조사되었다(4).

이러한 건강기능성 면역증강 소재 중에서 $\beta$-glucan이 포 함되는데, 포도당(glucose)이 $\beta-1,3$ 결합, $\beta-1,4$ 결합, 또는 $\beta$ $-1,6$ 결합 등으로 구성된 다당류를 총칭하며, 버섯, 효모 등 미생물의 세포벽 또는 세포외의 다당류에 포함되어 있거나 (5), 보리, 귀리와 같은 곡물의 식이섬유에 포함 되어있다고 알려져 있다(6). 하지만 식물 유래의 $\beta$-glucan은 대량 생산 에 제한이 있고, 버섯의 $\beta$-glucan 또한 추출 과정의 어려움 과 높은 가격으로 인하여 많은 제약이 있어왔다(7). Aureobasidium pullulans는 흑효모라고 알려져 있는 균류로 수용성이고 낮은 점도를 갖는 분자량이 작은(약 $100 \mathrm{kDa})$ $\beta-1,3 / 1,6$-glucan 만을 생성하는데, 이 $\beta-1,3 / 1,6$-glucan은 암 세포 생장과 간 전이를 억제하는데 효과가 있다고 보고되어 있다(8). $\beta$-glucan이 면역체계에 미치는 근본적인 영향에 대한 연구는 $\beta$-glucan의 특이적 수용체인 dectin-1(DC associated C-type Lectin-1)이 보고되면서 가속화 되었다(9). Dectin-1은 선천면역에 관여하는 pattern recognition receptors(PRRs)에 속하며 외부 항원물질의 특이적 패턴을 인식하여 결합하는 특징을 갖고 있어 항원이 갖는 종의 특성은 구분하지 않고 다양한 범위의 병원체를 빠르게 인식 할 수 있다(10). 그러므로 Dectin-1은 식물이나 세균, 곰팡이 등 다양한 외부항원에서 생성되는 $\beta$-glucan에 대한 인지가 가능하다(11). Dectin-1 receptor는 neutrophils, natural
killer(NK) 세포, B-세포 및 T-세포 등의 면역 세포에서 발현 이 확인되었고 그 외에도 다양한 세포 및 조직에서 광범위 하게 발현됨이 보고되었다 $(10,12)$.

또 한 가지의 건강기능성 면역증강 소재로 프로바이오틱 스 생균제가 사용되고 있는데, 이에 해당하고 있는 것은

Bifidobacterium속, Lactobacillus속, Enterococcus속, Clostridium butyricum, Lactobacillus sporogenes, Bacillus subtilis 및 Bacillus polyfermenticus 등이 있으며 이들의 면역조절 및 항암기능에 대한 연구들이 보고되고 있다(13). 특히, Lactobacillus균은 장내에 정상적으로 존재하는 균으로 면 역증강, 항균, 항바이러스 효과 등을 나타내는 것으로 보고 되었다(14). 유산균의 연구는 생균의 기능에 관한 것으로 한정되어 왔으나, 최근에는 유산균 구성성분(cell component)에 의한 면역 활성 signal transduction 기전에 관한 연구도 시도 되어진 바 있다. 최근 연구에 의하면 Lactobacillus균을 알레르기 환자에게 경구 투여한 결과, 장 점막의 기능이 증진된 것으로 나타났다(15). 또한,

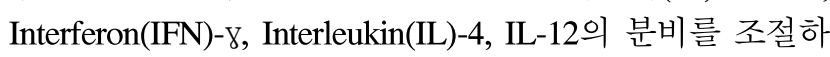
여 Th2 세포로의 분화를 Th1 세포로 전환시키는 것으로 나타났다(16). 이러한 연구 결과를 바탕으로 최근에는 알레 르기 예방 및 치료에 효과적인 방법으로 프로바이오틱스의 이용을 제안하고 있다(17).

이와 같이 $\beta$-glucan과 유산균이 모두 면역증진효과에 대 하여 효과적이라는 여러 연구결과들이 발표되었고 본 연구 에 앞서 발표한 $\beta-1,3 / 1,6$-glucan의 면역증진효과(18)의 in vitro 연구가 효과적이었음을 알 수 있었다. 본 연구에서는 $\beta-1,3 / 1,6-$ glucan과 함께 유산균을 첨가한 군들의 면역증진 효과를 실험동물 모델에서 알아보고자 조사하였다.

\section{재료 및 방법}

\section{$\beta-1,3 / 1,6-$ glucan과 유산균}

B-1,3/1,6-glucan은 $A$ pullulans로부터 Kim 등(19)의 연구 내용에 따라 상업적 대용량 생산에 따라 생산한 선일바이오 (주)(Jangheung, Korea)로 부터 공급받았으며, 유산균은 in vitro상에서 면역활성력이 확인된 유산균 Lactobacillus plantarum KKY-135를 생명공학연구원 전북분원 (Jeongeup, Korea)으로부터 공급받아 사용하였다.

\section{동물처리}

실험동물은 $20 \mathrm{~g}$ 내외의 4주령 암컷 $\mathrm{C} 57 \mathrm{BL} / 6$ 마우스를 이용하였고 남부대학교 실험동물위원회의 승인(승인번호: 201702)을 받은 후 실험을 실시하였다. 중앙실험동물 (주)(Seoul, Korea)에서 $20 \mathrm{~g}$ 내외의 4주령 암컷 C57BL/6 마우스를 공급받았으며, 명암은 12시간(light/dark cycle), 온도는 $23 \pm 2{ }^{\circ} \mathrm{C}$, 상대습도는 $50 \pm 5 \%$ 인 조건에서 1 주 동안 
적응기를 거쳐 실험에 이용하였다. 적응기간 동안 $\mathrm{AIN}-93 \mathrm{G}$ 식이와 음용수는 자유롭게 섭취하도록 하였다. 적응기간 중 건강하다고 판정된 동물에 대하여 체중을 측정하고 평균 체중에 가까운 개체를 선택하여 무작위법을 이용하여 군 분리를 실시하였다. 각 그룹별 6마리씩을 사용, 정상대조군 (NC), 감염 대조군(infection control(LP-BM5)), 양성대조군 (positive control, 홍삼 $200 \mathrm{mg} / \mathrm{kg}$ b.w 식이투여군(RG)), 유 산균투여군(LI), $\beta$-1,3/1,6-glucan 투여군(BI), $\beta$-1,3/1,6-glucan +유산균(LIBI), $\beta-1,3 / 1,6$-glucan+유산균(LIBh)으로 분리하 여 정상대조군을 제외한 모든 군의 마우스는 LP-BM5 $\mathrm{MuLV}$ 감염을 실시하였다. 모든 식이는 $\mathrm{AIN} 93 \mathrm{G}$ 를 기본식 이로 제작하였으며, 기본식이에 건조된 대조물질을 첨가하 여 식이를 제조하였고, 식이투여 동시에 LP-BM5 MuLV 감염 유발을 시작하였으며 실험 종료일까지 식이투여를 실시하였다. 실험기간 동안 식이와 음용수는 자유롭게 섭 취하도록 하였고 1 주일에 한 번씩 일정한 시간에 체중과 식이섭취량을 측정하였다.

\section{$\mathrm{LP}-\mathrm{BM} 5$ 바이러스 감염 및 식이 제작}

면역파괴 유발 동물 모델을 만들기 위하여 마우스에서 면역체계를 무너뜨리는 바이러스인 LP-BM5를 SC-1세포 의 배양액으로부터 얻은 뒤, 병원균에 민감한 종류인 C57BL/6 마우스에 복강 내 주사하여 1차 감염시키고, 5 일 후 동일한 방법으로 2차 감염시켜, LP-BM5 바이러스 감염 을 유발시켰다. 바이러스에 감염되어 면역 체계가 붕괴 된 마우스를 12주 동안 Table 1에서 제시한 식이조성에 따라 식이를 제공하면서 식이량, 체중을 매주 2회씩 측정하고 12 주 후 희생시켰다. 소재의 농도는 $250 \mathrm{mg} / \mathrm{kg}$ 의 body weight와 $500 \mathrm{mg} / \mathrm{kg}$ body weight가 되도록 조절하여 제작하 였다.

Table 1. Experimental design of animal

(n=6/group)

\begin{tabular}{|c|c|c|}
\hline Group & $\begin{array}{c}\text { Immune } \\
\text { deficiency }\end{array}$ & Diet supplement \\
\hline $\mathrm{NC}$ & - & AIN 93G \\
\hline LP-BM5 & + & AIN 93G \\
\hline RG & + & RedGinseng $200 \mathrm{mg} / \mathrm{kg}$ B.W. in AIN 93G \\
\hline $\mathrm{Ll}$ & + & Lactobacillus $1 \times 10^{9}$ CFU $/ \mathrm{kg}$ B.W in AIN 93G \\
\hline $\mathrm{Bl}$ & + & $\beta-1,3 / 1,6$-glucan $200 \mathrm{mg} / \mathrm{kg} \mathrm{B.W}$. in AIN 93G \\
\hline $\mathrm{LIBl}$ & + & $\begin{array}{l}\text { Lactobacillus } 1 \times 10^{9} \text { CFU } / \mathrm{kg} \mathrm{B.W.} \\
+\beta-1,3 / 1,6 \text {-glucan } 200 \mathrm{mg} / \mathrm{kg} \text { B.W. in AIN } 93 \mathrm{G}\end{array}$ \\
\hline $\mathrm{LlBh}$ & + & $\begin{array}{l}\text { Lactobacillus } 1 \times 10^{9} \text { CFU } / \mathrm{kg} \text { B.W. } \\
+\beta-1,3 / 1,6 \text {-glucan } 500 \mathrm{mg} / \mathrm{kg} \text { B.W. in AIN 93G }\end{array}$ \\
\hline
\end{tabular}

혈청 및 조직 처리

실험동물은 12 시간 절식하고 마취 후 개복하여 장기(비 장, 간, 림프절)을 적출한 다음, 중량을 측정하였다. 비장은
적출 즉시 Roswell Park Memorial Institute medium 1640 (RPMI-1640)(Hyclone Laboratories, Logan, Utah, USA)로 세척하여 $0.45 \mu \mathrm{m}$ cell strainer(BD biosciences, San Jose, CA, USA)을 사용하여 얻어진 세포 부유액을 Red blood cell lysing buffer(Sigma-Aldrich Co., St. Louis, MO, USA)로 적혈구를 용혈시켰다. 분리된 비장세포를 Cytokine과 $\mathrm{T}$, $\mathrm{B}$ 세포 증식능력의 측정에 이용하였으며, 분리한 복강대식 세포는 대식세포 활성화 측정에 이용하였다.

\section{세포 증식능 측정}

분리한 비장세포를 96-well plate에 각 well당 $1 \times 10^{6}$ cells 로 분주하였으며, T 세포 Mitogen인 ConA(Sigma-Aldrich Co.)를 $5 \mu \mathrm{g} / \mathrm{mL}$ 과 B 세포 Mitogen인 LPS(Sigma-Aldrich Co.)를 $5 \mu \mathrm{g} / \mathrm{mL}$ 을 처리한 후 $37^{\circ} \mathrm{C}, 5 \% \mathrm{CO}_{2}$ 에서 배양하였다. 48시간 후 Ez-Cytox(Dugen, Seoul, Korea)용액 $20 \mu \mathrm{L}$ 를 첨가 하고 ELISA reader(VERSAMAXSL- 20 Molecular Devices, Korea)를 이용하여 $450 \mathrm{~nm}$ 에서 흡광도를 측정하였다.

\section{Cytokine 분비량 측정}

분리한 비장세포를 96-well plate에 각 well당 $1 \times 10^{6}$ cells 씩 분주하였으며, IL-2, IL-4, IL-10, IL-12, IL-15, IFN-8는 ConA를 각 $5 \mu \mathrm{g} / \mathrm{mL}$ 로 처리하였다. IL-6, TNF- $a$ 는 LPS를 각 $5 \mu \mathrm{g} / \mathrm{mL}$ 로 처리하였으며, $37^{\circ} \mathrm{C}, 5 \% \mathrm{CO}_{2}$ 에서 배양하여 $\mathrm{IL}-2, \mathrm{IL}-4, \mathrm{IL}-6, \mathrm{IL}-10, \mathrm{TNF}-\mathrm{a}$ 는 24 시간 후, IL-12, IL-15는 48시간 후, IFN-8는 72시간 후에 상층액을 수거하여 Duoset ELISA kit(R\&D system, Minneapolis, MN, USA)를 이용하 여 ELISA reader로 $650 \mathrm{~nm}$ 에서 흡광도를 측정하였다.

\section{혈청 Immunoglubulin 측정}

분리한 혈청으로 Immunoglobulin $\mathrm{G}(\mathrm{IgG})$, Immunoglobulin $\mathrm{A}(\operatorname{IgA})$, Immunoglobulin $\mathrm{E}(\mathrm{IgE})$ mouse elisa kit(Abcam, Cambridge, MA, UK)를 이용하여 ELISA reader로 $570 \mathrm{~nm}$ 에서 흡광도를 측정하였다.

\section{통계처리}

본 연구는 SPSS(Statistical Package for the Social Science) version 22 프로그램을 이용하여 분석하였으며, 모든 측정 결과는 평균(mean)표준편차(standard deviation, SD)로 표 시하였음. 그룹간의 통계적 유의성을 Duncan's multiple range test를 실시하였으며 $\mathrm{p}<0.05$ 수준에서 유의성의 여부 를 검증하였다.

\section{결과 및 고찰}

\section{대식세포 활성능의 조사}

in vivo 면역 조절 효능 실험 전 $\beta-1,3 / 1,6$-glucan, 유산균, $\beta-1,3 / 1,6-$ glucan+유산균 혼합물식이 농도 결정을 위하여 
대식세포 활성능을 측정한 결과 Fig. 1에 나타내었다. 실험 결과, $\mathrm{NC}$ 군에 비하여 inhibitor군이 $12.3 \pm 0.2$, zymosan+ inhibitor군에서 $18.1 \pm 2.4 \%$ 의 대식세포 활성능을 보여 유의 적으로 차이가 없었지만, $\mathrm{Ll}+\mathrm{Bl}$ 군, $\mathrm{Ll}+\mathrm{Bh}$ 군, zymosan군이 각가 $117.6 \pm 14.7 \%, 115.6 \pm 4.4 \%, 102.6 \pm 5.7 \%$ 를 보여 $\mathrm{NC}$, inhibitor, zymosan+inhibitor에 비하여 유의적으로 대식세포 활성능이 증가는 것으로 나타났다. 이는 우리와 유사한 연 구에서도 확인이 되어 경향성이 동일하다고 생각할수 있다 (20). 그러나 $\mathrm{Lh}+\mathrm{Bl}$ 군이 $17.2 \pm 0.8 \%$ 그리고 $\mathrm{Lh}+\mathrm{Bh}$ 군이 $16.1 \pm 0.2 \%$ 를 보여 NC, inhibitor, zymosan+inhibitor군과 비 교하여 유의적인 차이가 없는 것으로 확인되었다. 이러한 결과로 보았을 때 $\beta-1,3 / 1,6$-glucan과 L plantarum KKY-135 균주를 동시에 처리하였을 경우, 면역 증가율이 높아짐을 알 수 있었지만, 낮은 농도의 유산균에서 효과적 이였지만, 높은 농도의 유산균에서는 $\beta-1,3 / 1,6$-glucan의 농도와는 상 관없이 낮은 대식세포 활성능을 보여 추가적인 연구가 필요 할 것으로 판단된다.

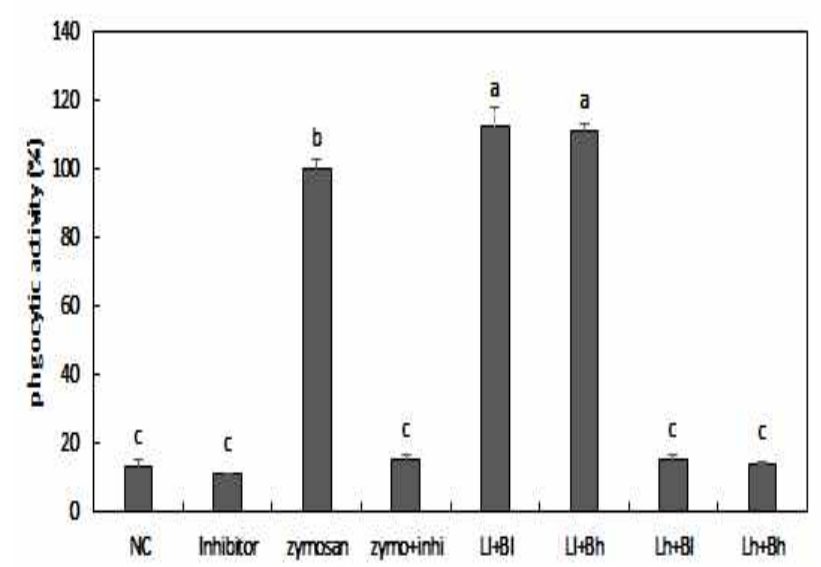

Fig. 1. Effect of $\beta$-glucan and Lactobacillus on phgocytic activity from macrophage in C87BL/6 mice.

Data were expressed as percent growth rate of cells cultured in presence of $\beta-1,3 / 1,6$-gucan, compared with treated zymosan (cell+zy) cells, taken as $100 \%$. Values are presented as means \pm SD. Different letters show a significantly difference at $p<0.05$ as determined by Duncan's multiple range test.

$\mathrm{NC}$, cell only; Inhibitor, cell+zymosan inhibitor; zymosan, cell+zymosan; zymo+inhi, cell+zymosan+zymosan inhibitor; $\mathrm{Ll}+\mathrm{Bl}$, Lactobacillus $1 \times 10^{9} \mathrm{CFU}+\beta-1,3 / 1,6$-glucan 10 $\mu \mathrm{g} / \mathrm{mL} ; \quad \mathrm{Ll}+\mathrm{Bh}, \quad$ Lactobacillus $1 \times 10^{9} \quad \mathrm{CFU}+\beta-1,3 / 1,6$-glucan $150 \mu \mathrm{g} / \mathrm{mL} ; \quad \mathrm{Lh}+\mathrm{Bl}$, Lactobacillus $1 \times 10^{10} \mathrm{CFU}+\beta-1,3 / 1,6$-glucan $10 \mu \mathrm{g} / \mathrm{mL}$; Lh+Bh, Lactobacillus $1 \times 10^{10}$ CFU+ $\beta-1,3 / 1,6$-glucan $150 \mu \mathrm{g} / \mathrm{mL}$

\section{몸무게 및 조직 무게 변화}

LP-BM5 murine AIDS virus에 감염된 면역 결핍동물 모 델은 인간 $\mathrm{AIDS}$ 와 유사하게 비장비대증과 림프절 장애 등의 병리학적 변화를 나타낸다고 알려져 있다. 비장은 면 역세포가 집중되어 있는 면역체계에서 가장 중요한 림프기 관으로, 항원이 제시되거나 면역반응이 급속하게 진행하면 서 이로 인한 반응으로 크기가 증가하여 비장비대증이 유발 된다. 적응면역반응의 시작에 중요한 기능을 담당하는 림 프절도 감염, 자가면역질환에 의한 면역반응으로 크기가
증가하게 된다(21,22). 또한 LP-BM5 murine AIDS virus에 감염 시 활성산소에 의한 산화적 스트레스가 급격히 증가하 며 이로 인하여 간세포의 염증이 유발되고 지방간 등의 간질환이 일어나는 것으로 알려져 있다(23). 따라서 이러한 조직의 무게 증가는 LP-BM5 murine AIDS virus 감염이 정상적으로 발현되고 있음을 나타내는 지표가 되기도 한 다. 본 연구에서는 마우스의 몸무게 변화와 조직 무게 변화 를 측정하여 이러한 병리학적 변화를 관찰하였다.

$\beta-1,3 / 1,6$-glucan, 유산균, $\beta-1,3 / 1,6$-glucan+유산균이 실 험동물의 체중변화와 식이효율에 미치는 영향을 조사하였 다. 실험기간 10 주 동안 $\beta$-1,3/1,6-glucan, 유산균, $\beta$ -1,3/1,6-glucan+유산균이 LP-BM5 murine AIDS virus에 감 염된 면역 결핍동물 모델의 체중 변화와 식이효율에 미치는 영향을 실험한 결과는 Table 2에 나타내었다. 체중과 식이 효율을 측정한 결과, $\mathrm{NC}$ 군에 비해 모든 식이섭취군에서 유의적으로 차이가 없음을 확인하였다. 따라서 본 실험을 통해 얻어진 연구 결과의 경우, 실험 대상의 식이섭취에 따라 독성 여부 및 면역 활성에 영향을 주지 않았음을 확인 할 수 있었다.

Table 2. Mice body weight gain, food consumption and food efficiency rate of experimental groups for 10 weeks

\begin{tabular}{|c|c|c|c|}
\hline Group $^{1)}$ & $\begin{array}{l}\text { Weight gain } \\
\text { (g) }\end{array}$ & $\begin{array}{l}\text { Food consumption }{ }^{3)} \\
\text { (g/day) }\end{array}$ & $\begin{array}{c}\mathrm{FEF}^{4)} \text { (Food efficiency } \\
\text { rate) }\end{array}$ \\
\hline $\mathrm{NC}$ & $16.75 \pm 1.59$ & $2.97 \pm 0.61$ & $10.08 \pm 0.96$ \\
\hline LP-BM5 & $16.50 \pm 1.25$ & $2.67 \pm 0.71$ & $11.02 \pm 0.84$ \\
\hline RG & $16.88 \pm 3.96$ & $3.16 \pm 0.48$ & $9.54 \pm 2.24$ \\
\hline $\mathrm{Ll}$ & $19.77 \pm 2.11$ & $3.12 \pm 0.52$ & $11.31 \pm 1.21$ \\
\hline $\mathrm{Bl}$ & $16.60 \pm 2.54$ & $3.16 \pm 0.42$ & $9.39 \pm 1.44$ \\
\hline $\mathrm{Ll}+\mathrm{Bl}$ & $17.92 \pm 3.71$ & $3.04 \pm 0.37$ & $10.52 \pm 2.18$ \\
\hline $\mathrm{Ll}+\mathrm{Bh}$ & $17.62 \pm 3.33$ & $3.05 \pm 0.34$ & $10.32 \pm 1.95$ \\
\hline
\end{tabular}

${ }^{11} \mathrm{NC}$, normal control; LP-BM5, LP-BM5 virus injection; RG, LP-BM5 virus injection+RedGinseng $200 \mathrm{mg} / \mathrm{kg} \mathrm{B.W}$.; Ll, LP-BM5 virus injection+Lactobacillus $1 \times 10^{9}$ CFU/kg B.W.; Bl, $\beta-1,3 / 1,6$-glucan $200 \mathrm{mg} / \mathrm{kg} \mathrm{B.W.;} \mathrm{Ll+Bl,} \mathrm{LP-BM5} \mathrm{virus}$ injection+Lactobacillus $1 \times 10^{9}$ CFU/kg B.W.+ $+3-1,3 / 1,6$-glucan $200 \mathrm{mg} / \mathrm{kg}$ B.W.; $\mathrm{Ll}+\mathrm{Bh}$, LP-BM5 virus injection+Lactobacillus $1 \times 10^{\circ}$ CFU/kg B.W. $+\beta-1,3 / 1,6$-glucan $500 \mathrm{mg} / \mathrm{kg} \mathrm{B.W..}$

${ }^{2)}$ Weight gain $(\mathrm{g} / 10 \mathrm{weeks})=$ final body weight (g)-initial body weight $(\mathrm{g})$.

${ }^{3}$ Food consumption ( $g /$ day) $=$ food consumption ( $g /$ day).

${ }^{4}$ FER (Food efficiency rate $)=\{$ weight $(\mathrm{g}) /$ food intake $(\mathrm{g})\} \times 100$.

또한 실험동물의 장기무게 변화를 측정한 결과, Table 3에 나타내었다. 비장(spleen)은 바이러스 주입 후 일반 AIN-93G 식이를 섭취한 infection군이 $0.53 \mathrm{~g}$ 으로 바이러스 감염이 안 된 $\mathrm{NC}$ 군 $0.10 \mathrm{~g}$ 에 비해 유의적으로 증가하였으 며, 바이러스가 감염된 infection군에 비하여 식이를 섭취한 모든 군에서 유의적으로 비장의 무게가 감소하였다. 림프 절(Lymph node)는 바이러스 주입 후 일반 AIN-93G 식이를 섭취한 infection군이 $1.70 \mathrm{~g}$ 으로 바이러스 감염이 안 된 
$\mathrm{NC}$ 군 $0.02 \mathrm{~g}$ 에 비해 유의적으로 증가하였으나, $\beta-1,3 /$ 1,6-glucan, 유산균의 주입군에서 유의하게 무게감소를 보 여, $\beta-1,3 / 1,6$-glucan, 유산균의 주입군에서 비장과 림프절 에 대한 비대증을 억제 및 완화시켰음을 확인할 수 있었다. 그러나 간(liver)와 신장(kidney)의 무게는 그룹간의 유의적 인 차이가 나타나지 않아 산화적 스트레스에 의한 간의 무게 증가와 $\beta-1,3 / 1,6$-glucan, 유산균의 연관관계는 추가적 인 조사가 필요하다.

Table 3. liver, kidney, spleen, and lymph node weights of experimental groups for 10 weeks

\begin{tabular}{ccccc}
\hline Group $^{1)}$ & Liver (g) & Kideny (g) & Spleen (g) & Lymph node (g) \\
\hline NC & $1.32 \pm 0.13^{2)}$ & $0.31 \pm 0.02^{\mathrm{b}}$ & $0.08 \pm 0.03^{\mathrm{d}}$ & $0.02 \pm 0.01^{\mathrm{d}}$ \\
LP-BM5 & $1.6 .3 \pm 0.14$ & $0.32 \pm 0.02^{\mathrm{ab}}$ & $0.53 \pm 0.01^{\mathrm{a}}$ & $1.70 \pm 0.27^{\mathrm{a}}$ \\
RG & $1.32 \pm 0.44$ & $0.33 \pm 0.02^{\mathrm{ab}}$ & $0.43 \pm 0.05^{\mathrm{bc}}$ & $0.78 \pm 0.14^{\mathrm{c}}$ \\
Ll & $1.66 \pm 0.17$ & $0.31 \pm 0.02^{\mathrm{b}}$ & $0.44 \pm 0.07^{\mathrm{b}}$ & $0.95 \pm 0.18^{\mathrm{bc}}$ \\
Bl & $1.31 \pm 0.24$ & $0.36 \pm 0.02^{\mathrm{a}}$ & $0.46 \pm 0.08^{\mathrm{c}}$ & $0.73 \pm 0.08^{\mathrm{c}}$ \\
Ll+Bl & $1.57 \pm 0.40$ & $0.34 \pm 0.04^{\mathrm{ab}}$ & $0.48 \pm 0.04^{\mathrm{b}}$ & $1.12 \pm 0.06^{\mathrm{b}}$ \\
Ll+Bh & $1.45 \pm 0.28$ & $0.31 \pm 0.02^{\mathrm{ab}}$ & $0.47 \pm 0.08^{\mathrm{c}}$ & $1.05 \pm 0.11^{\mathrm{b}}$ \\
\hline
\end{tabular}

${ }^{1)} \mathrm{NC}$, normal control; LP-BM5, LP-BM5 virus injection; RG, LP-BM5 virus injection+RedGinseng $200 \mathrm{mg} / \mathrm{kg} \mathrm{B.W}$; Ll, LP-BM5 virus injection+Lactobacillus $1 \times 10^{9}$ CFU/kg B.W; Bl, $\beta-1,3 / 1,6$-glucan $200 \mathrm{mg} / \mathrm{kg} \mathrm{B.W}$; Ll+Bl, LP-BM5 virus injection+Lactobacillus $1 \times 10^{9}$ CFU $/ \mathrm{kg}$ B.W+ $\beta$-1,3/1,6-glucan $200 \mathrm{mg} / \mathrm{kg}$ B.W; $\mathrm{L}+\mathrm{Bh}$, LP-BM5 virus injection+Lactobacillus $1 \times 10^{9} \mathrm{CFU} / \mathrm{kg} \mathrm{B} . \mathrm{W}+\beta-1,3 / 1,6$-glucan $500 \mathrm{mg} / \mathrm{kg} \mathrm{B.W.}$

${ }^{2)}$ Values are presented as means \pm SD. Different letters show a significantly difference at $p<0.05$ as determined by Duncan's multiple range test.

\section{$\mathrm{T}$ 세포 및 $\mathrm{B}$ 세포 증식능 측정}

AIDS virus의 gp120은 CD4와 높은 친화력을 가져 CD4+ $\mathrm{Th}$ 세포, 대식세포, 수지상세포와 결합하여 세포 내로 들어 가 세포의 기능을 떨어뜨리고 바이러스 복제를 증가시킨다 고 알려져 있다(24). 또한 CD21 단백질을 감소시켜 B 세포 의 정상적인 기능을 어렵게 하고 필요치 않은 항체를 과량 생산하여 기회 감염에 대한 면역의 반응능력을 감소시킨 다. Moir 등(25)의 연구에서 HIV 감염에 의하여 $\mathrm{T}$ 세포 및 $\mathrm{B}$ 세포의 수가 비감염군에 비하여 유의적으로 감소하였 다고 보고하였다. 이러한 면역세포 수 감소에 대한 기전은 정확하게 밝혀지지 않았지만 자가세포사멸에 의한 것으로 알려져 있다(26,27). 본 연구에서는 실험기간 10 주 동안 $\beta$ -1,3/1,6-glucan, 유산균, $\beta-1,3 / 1,6$-glucan+유산균이 LP-BM5 murine AIDS virus에 감염된 면역 결핍동물 모델의 $\mathrm{T}$ cell과 $\mathrm{B}$ cell의 세포증식능에 미치는 영향을 실험한 결과는 Fig. 2에 나타내었다.

$\mathrm{T}$ 세포 증식능 측정 결과 바이러스 감염이 안 된 $\mathrm{NC}$ 군에 비해 바이러스 주입 후 일반 AIN-93G 식이를 섭취한 infection군의 증식능이 유의적으로 감소하였다. 식이섭취 군 모두에서 infection군에 비하여 유의적으로 증가하였으 며, 특히, $\mathrm{Bl}$ 군이 $77.3 \pm 6.2 \%, \mathrm{Ll}+\mathrm{Bh}$ 군이 $80.4 \pm 8.4 \%$ 로
$45.7 \pm 3.5 \%$ 인 infection군에 비하여 유의적으로 증가하였으 며 면역조절로 잘 알려진 $\mathrm{RG}(88.7 \pm 8.6 \%)$ 군과 비교하여도 유의적으로 감소된 $\mathrm{T}$ 세포 증식능을 증가시키는 것으로 나타났다. B 세포 증식능 측정 결과 바이러스 감염이 안된 $\mathrm{NC}$ 군에 비해 바이러스 주입 후 일반 AIN-93G 식이를 섭취 한 infection군의 증식능이 유의적으로 증가하였음을 알 수 있었다. 또한, 식이섭취군 모두에서 infection군에 비하여 유의적으로 감소하였음을 알 수 있었으며, 특히, $\mathrm{Ll}$ 군, $\mathrm{Ll}+\mathrm{Bl}$ 군, $\mathrm{Ll}+\mathrm{Bh}$ 군이 각각 $117.8 \pm 4.7 \%, 149.6 \pm 4.3 \%$ 그리고 $134.6 \pm 1.8 \%$ 를 나타내어 $177.3 \pm 3.4 \%$ 로 증가한 infection군 에 비하여 유의적으로 낮다진 것을 확인하였는데 면역조절 로 잘 알려진 $\mathrm{RG}$ 군(126.4 $\pm 3.7 \%$ )과 비교하여도 유의적으로

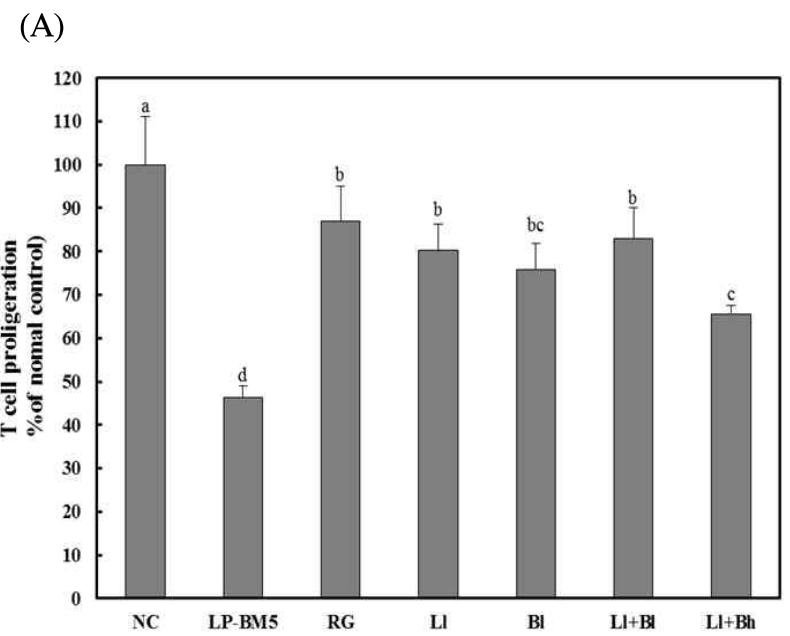

(B)

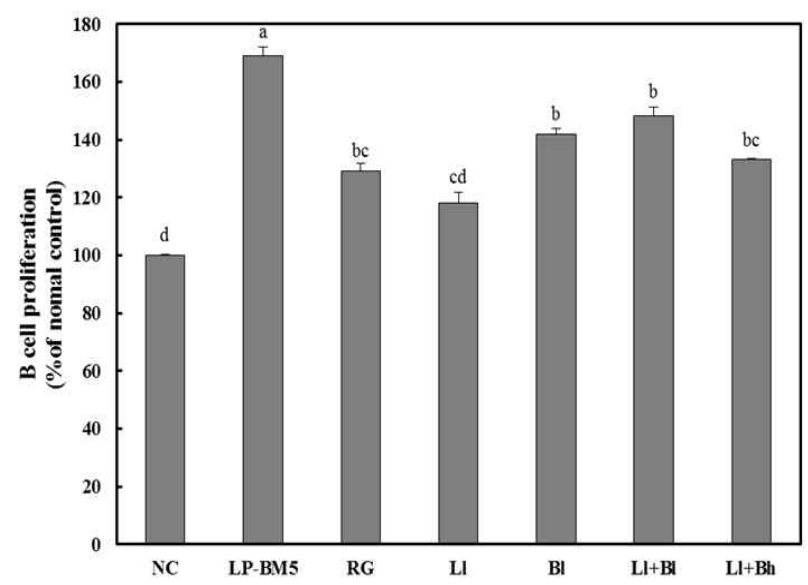

Fig. 2. Effect of $\beta$-glucan and Lactobacillus on $\mathrm{T}$ cell (A) and B cell (B) proliferations from splenocytes in C87BL/6 mice treated with or without LP-BM5 virus.

Values are presented as means $\pm \mathrm{SD}$. Different letters show a significantly difference at $p<0.05$ as determined by Duncan's multiple range test.

NC, non infection; LP-BM5, LP-BM5 virus infection; RG, LP-BM5 virus infection+Red Ginseng $200 \mathrm{mg} / \mathrm{kg}$ B.W; Ll, LP-BM5 virus infection+Lactobacillus $1 \times 10^{9}$ CFU $/ \mathrm{kg} \mathrm{B.W}$; $\mathrm{Bl}$, LP-BM5 virus infection+ $\beta$-1,3/1,6-glucan $200 \mathrm{mg} / \mathrm{kg} \mathrm{B.W}$; Ll+Bl, LP-BM5 virus infection+Lactobacillus $1 \times 10^{9}$ CFU/kg B.W and $\beta-1,3 / 1,6$-glucan $200 \mathrm{mg} / \mathrm{kg} \mathrm{B.W}$; L1+Bh, LP-BM5 virus infection+Lactobacillus $1 \times 10^{9}$ CFU/kg B.W and $\beta$-1,3/1,6-glucan 500 $\mathrm{mg} / \mathrm{kg}$ B.W. 


\section{증가된 $\mathrm{B}$ 세포 증식능을 감소되었다.}

\section{Th1/Th2 cytokines 생성측정}

$\mathrm{CD} 4+\mathrm{Th}$ 세포에는 Th1 type cytokines을 생성하는 Th1 세포와 Th2 type cytokines을 생성하는 $\mathrm{Th} 2$ 세포가 있다. Th1 type cytokines은 주로 대식세포의 활성을 증가시켜 탐식작용을 활성화시키며, Th2 type cytokines은 B 세포의 활성을 자극, 항체 생산을 증가시킨다. 이러한 $\mathrm{Th} 1 / \mathrm{Th} 2$ typecytokines의 상호보완적인 조절에 의하여 면역균형을 유지시킨다(28). 하지만 LP-BM5 murine AIDS virus에 감염 은 Th1 type cytokines을 감소시키고 Th2 type cytokines을

(A)

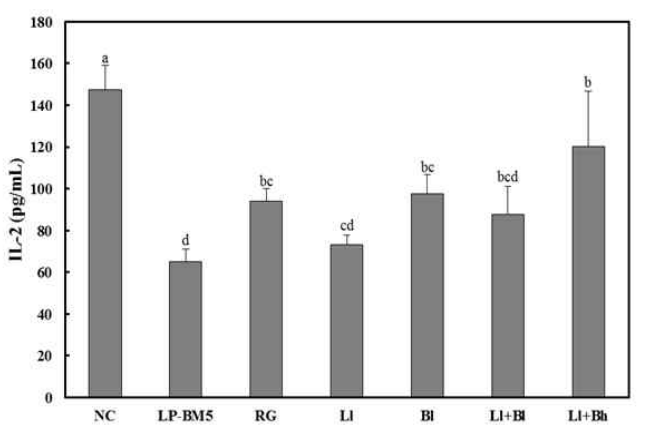

(C)

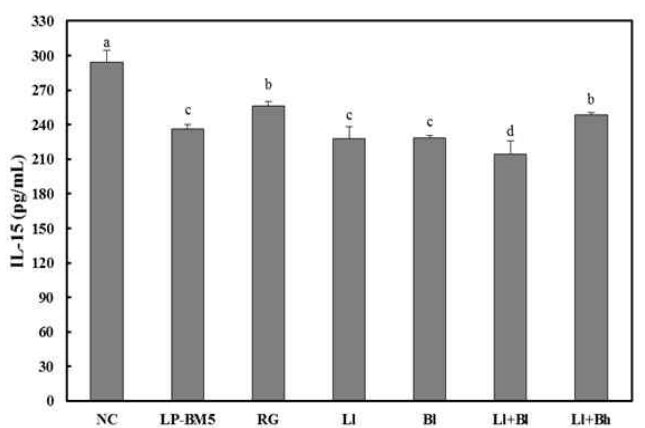

(E)

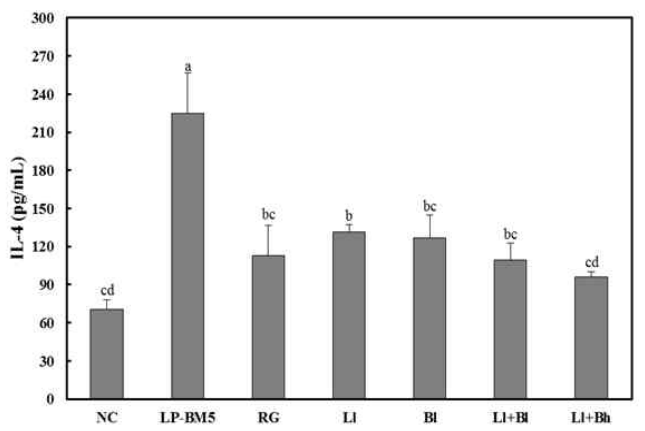

증가 시켜 불균형을 일으키고 면역조절 능력을 떨어뜨리게 된다(29).

실험 동물을 대상으로 10 주 동안 $\beta-1,3 / 1,6$-glucan, 유산 균, $\beta$-1,3/1,6-glucan+유산균이 LP-BM5 murine AIDS virus 에 감염된 면역 결핍동물 모델의 Th1 type cytokine 분비량 결과는 Fig. 3에 나타내었다. Th1 type cytokine 중 IFN- 8 는 $\mathrm{CD} 4+\mathrm{Th}$ 세포의 분화와 대식세포의 기능을 자극시키는 역할을 한다. Th1 type cytokine인 IL-2는 CD4+ Th 세포의 증식과 분화에 필요한 cytokine이다(30). IL-2 측정 결과 바 이러스 감염이 안 된 $\mathrm{NC}$ 군에서 $146.9 \pm 7 \mathrm{pg} / \mathrm{mL}$ 에 비해 바이 러스 주입 후 일반 AIN-93G 식이를 섭취한 infection에서

(B)

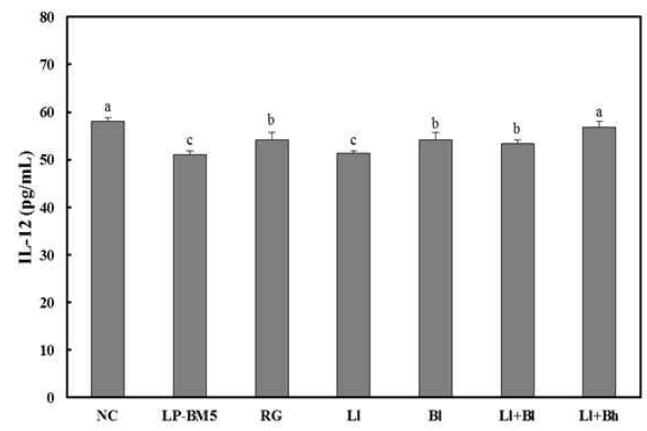

(D)

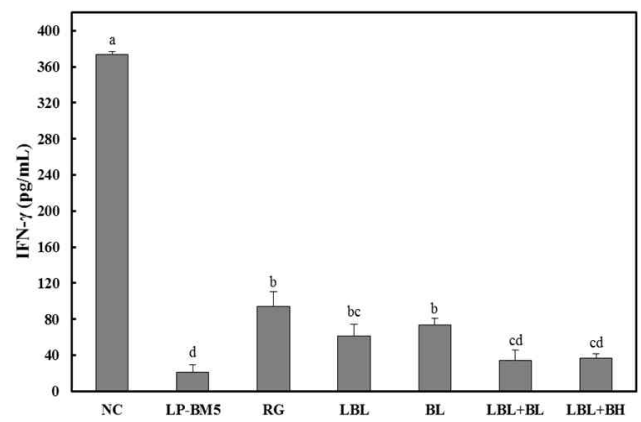

Fig. 3. Effect of $\beta$-glucan and Lactobacillus on Th1 cytokines from splenocytes in C87BL/6 mice with or without LP-BM5 virus.

A, IL-2; B, IL-12; C, IL-15; D, INF-gamma; E, TNF-alpha.

Values are presented as means \pm SD. Different letters show a significantly difference at $p<0.05$ as determined by Duncan's multiple range test.

NC, non infection; LP-BM5, LP-BM5 virus infection; RG, LP-BM5 virus infection+Red Ginseng $200 \mathrm{mg} / \mathrm{kg} \mathrm{B.W}$; Ll, LP-BM5 virus infection+Lactobacillus $1 \times 10^{9} \mathrm{CFU} / \mathrm{kg}$ B.W; Bl, LP-BM5 virus infection+ $\beta-1,3 / 1,6-$ glucan $200 \mathrm{mg} / \mathrm{kg}$ B.W; Ll+Bl, LP-BM5 virus infection+Lactobacillus $1 \times 10^{9}$ CFU $/ \mathrm{kg}$ B.W and $\beta-1,3 / 1,6-\mathrm{glucan} 200 \mathrm{mg} / \mathrm{kg}$ B.W; Ll+Bh, LP-BM5 virus infection+Lactobacillus $1 \times 10^{9}$ CFU/kg B.W and $\beta-1,3 / 1,6-$ glucan $500 \mathrm{mg} / \mathrm{kg} \mathrm{B.W}$. 
$64.5 \pm 8.2 \mathrm{pg} / \mathrm{mL}$ 으로 증식능이 유의적으로 감소하였다. $\mathrm{Bl}$ 군은 $96.7 \pm 8.9 \mathrm{pg} / \mathrm{mL}$ 으로 infection군에 비하여 유의적으로 회복되었으나 $\mathrm{Ll}$ 군과 $\mathrm{Ll}+\mathrm{Bl}$ 군은 각가 $72.5 \pm 4.7,83.6 \pm 14.5$ $\mathrm{pg} / \mathrm{mL}$ 으로 증가하였으나 infection군과 유의적인 차이를 보이지 않았다. 특히, $\mathrm{Ll}+\mathrm{Bh}$ 군은 $120.2 \pm 26.8 \mathrm{pg} / \mathrm{mL}$ 으로 infection군에 비하여 유의적으로 증가하였으며 면역조절 로 잘 알려진 $\mathrm{RG}$ 군과 비교하여도 유의적으로 감소된 $\mathrm{IL}-2$ 분비량을 증가시키는 것을 확인할 수 있었다. 따라서 이러 한 결과로 보아 $\beta-1,3 / 1,6$-glucan군, $\beta-1,3 / 1,6$-glucan+유산 균 저농도처리군에서 면역 효능이 증가함을 확인할 수 있었 다. IL-12 측정 결과 바이러스 감염이 안 된 $58.3 \pm 2.3 \mathrm{pg} / \mathrm{mL}$ 을 나타낸 NC군에 비해 바이러스 주입 후 일반 AIN-93G 식이를 섭취한 infection군이 $50.6 \pm 2.1 \mathrm{pg} / \mathrm{mL}$ 으로 증식능이 유의적으로 감소하였으며, $\mathrm{Bl}$ 군과 $\mathrm{Ll}+\mathrm{Bl}$ 군은 각각 $57.2 \pm 2.4$ $\mathrm{pg} / \mathrm{mL}, 56.4 \pm 0.9 \mathrm{pg} / \mathrm{mL}$ 으로 infection군에 비하여 유의적으 로 증가 회복하였으나 $\mathrm{Ll}$ 군에서는 $50.9 \pm 0.4 \mathrm{pg} / \mathrm{mL}$ 으로 infection군과 유의적인 차이를 보이지 않았다. 특히, $\mathrm{Ll}+\mathrm{Bh}$ 군은 $58.9 \pm 1.3 \mathrm{pg} / \mathrm{mL}$ 으로 infection군 대비 유의적으로 높은 활성이었고, 면역조절로 잘 알려진 RG군과 비교하여도 유 사한 $\mathrm{IL}-12$ 분비량을 증가시키는 것으로 보아 $\beta-1,3 / 1,6-$ glucan+유산균 처리에 따른 이중 면역 효능이 있음을 확인 할 수 있었다. 한편 $\mathrm{IL}-15$ 분비량에서는 $253.2 \pm 2.8 \mathrm{pg} / \mathrm{mL}$ 을 분비한 $\mathrm{Ll}+\mathrm{Bh}$ 군은 $235.7 \pm 4.3 \mathrm{pg} / \mathrm{mL}$ 으로 감소한 infection 군에 비하여 유의적으로 증가하였으며 면역조절로 잘 알려 진 RG군 $(261.1 \pm 4.9 \mathrm{pg} / \mathrm{mL})$ 과 비교하여도 유의적으로 감소 된 IL-15분비량을 증가시켰으며, $\mathrm{FFN}-\gamma$ 측정 결과 바이러스 감염이 안 된 $\mathrm{NC}$ 군에서는 $375.9 \pm 2.7 \mathrm{pg} / \mathrm{mL}$ 에 비해 바이러 스 주입 후 일반 AIN-93G 식이를 섭취한 infection군은 $22.6 \pm 5.7 \mathrm{pg} / \mathrm{mL}$ 으로 증식능이 유의적으로 감소하였으며, $\mathrm{Bl}$ 군이 $78.4 \pm 6.2 \mathrm{pg} / \mathrm{mL}$ 으로 감염군에 비하여 회복되는 것 을 확인하였다. 한편 TNF-a 측정 결과 바이러스 감염이 안 된 $\mathrm{NC}$ 군에서는 $42.8 \pm 5.2 \mathrm{pg} / \mathrm{mL}$ 에서 바이러스 주입 후 일반 AIN-93G 식이를 섭취한 infection군은 $353.1 \pm 22.3$ $\mathrm{pg} / \mathrm{mL}$ 의 증식능이 크게 증가하였으며, $481.5 \pm 11.2 \mathrm{pg} / \mathrm{mL}$ 까지 증가한 $\mathrm{Ll}+\mathrm{Bl}$ 군의 경우를 제외한 식이를 섭취한 모든 군은 infection군에 비하여 유의적으로 감소하였다.

Th2 cytokine 분비량 측정 결과, 실험기간 10 주 동안 $\beta$ -1,3/1,6-glucan, 유산균, $\beta-1,3 / 1,6$-glucan+유산균이 LP-BM5 murine AIDS virus에 감염된 면역 결핍동물 모델의 Th2 type cytokine 분비량 결과는 Fig. 4에 나타내었다. IL-4 측정 결과 바이러스 감염이 안 된 $\mathrm{NC}$ 군에서 $72.7 \pm 12.3 \mathrm{pg} / \mathrm{mL}$ 으 로 infection군에서 $226.7 \pm 36.2 \mathrm{pg} / \mathrm{mL}$ 으로 크게 유의적으로 증가하였으며, 식이를 섭취한 모든 군은 infection군에 비하 여 유의적으로 감소하는 경향을 나타내었다. 특히, $\mathrm{Ll}+\mathrm{Bh}$ 군에서 $93.4 \pm 8.2 \mathrm{pg} / \mathrm{mL}$ 으로 infection군에 비하여 유의적으 로 증가하였으며 면역조절로 잘 알려진 RG군 $(112.8 \pm 27.4$ $\mathrm{pg} / \mathrm{mL}$ )과 비교하여도 유의적으로 증가된 $\mathrm{IL}-4$ 분비량을

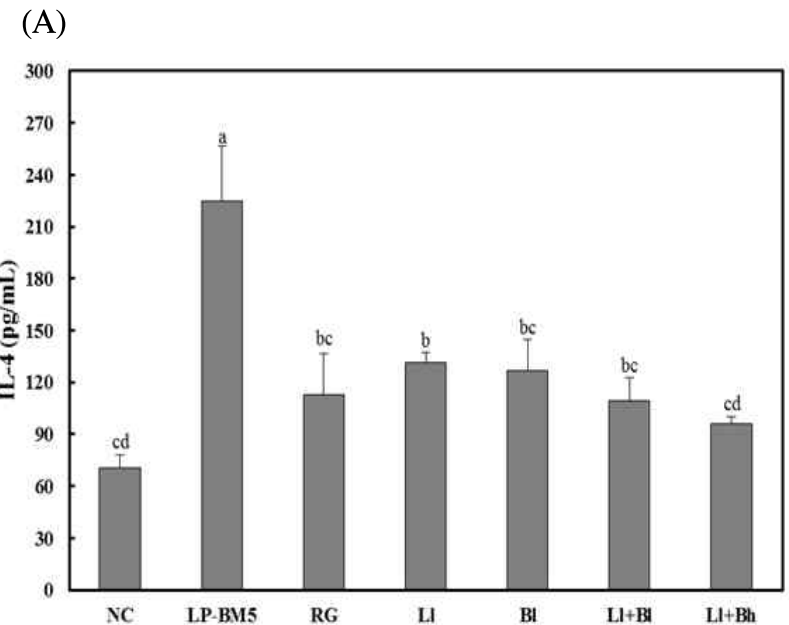

(B)

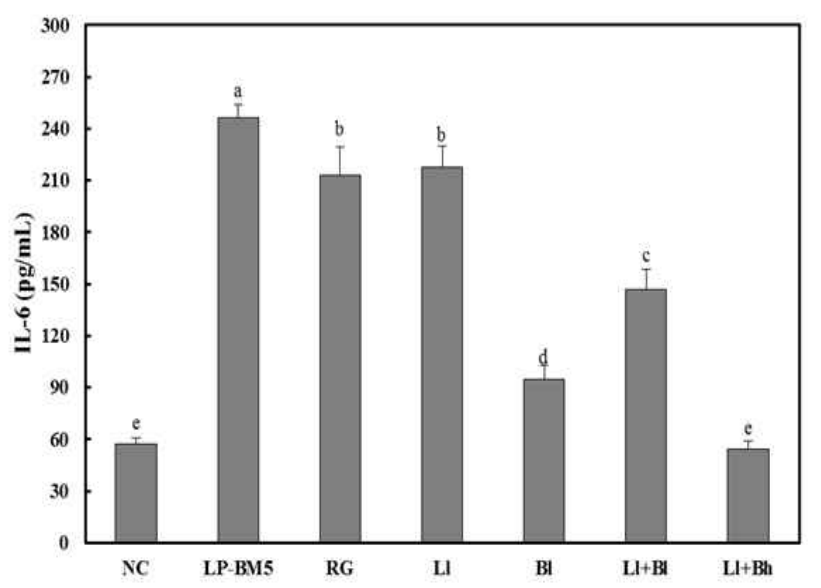

(C)

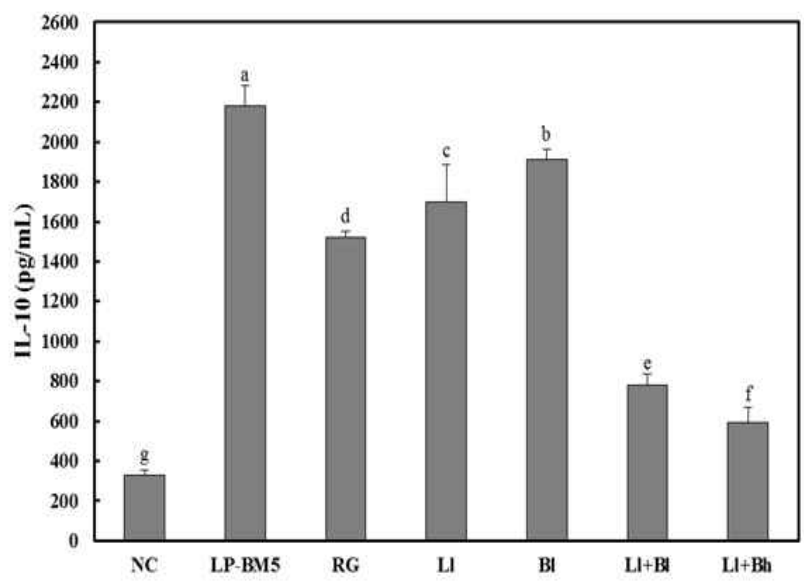

Fig. 4. Effect of $\beta$-glucan and Lactobacillus on Th2 cytokines from splenocytes in C87BL/6 mice with or without LP-BM5 virus.

A, IL-4; B, IL-6; C, IL-10.

Values are presented as means \pm SD. Different letters show a significantly difference at $\mathrm{p}<0.05$ as determined by Duncan's multiple range test.

NC, non infection; LP-BM5, LP-BM5 virus infection; RG, LP-BM5 virus infection+Red Ginseng $200 \mathrm{mg} / \mathrm{kg}$ B.W; Ll, LP-BM5 virus infection+Lactobacillus $1 \times 10^{9} \mathrm{CFU} / \mathrm{kg}$ B.W; $\mathrm{Bl}$, LP-BM5 virus infection+ $\beta$-1,3/1,6-glucan $200 \mathrm{mg} / \mathrm{kg} \mathrm{B.W}$; Ll+Bl, LP-BM5 virus infection+Lactobacillus $1 \times 10^{9}$ CFU/kg B.W and $\beta-1,3 / 1,6$-glucan $200 \mathrm{mg} / \mathrm{kg} \mathrm{B.W}$; Ll+Bh, LP-BM5 virus infection+Lactobacillus $1 \times 10^{9}$ CFU $/ \mathrm{kg} \mathrm{B.W}$ and $\beta-1,3 / 1,6$-glucan 500 $\mathrm{mg} / \mathrm{kg}$ B.W. 
감소시키는 것으로 나타났다. IL-6 측정 결과 바이러스 감 염이 안 된 $\mathrm{NC}$ 군에서는 $58.2 \pm 1.6 \mathrm{pg} / \mathrm{mL}$ 으로 $246.9 \pm 10.5$ $\mathrm{pg} / \mathrm{mL}$ 을 크게 증가한 infection군에 비하여 유의적으로 증 가하였으며, 식이를 섭취한 모든 군은 infection군에 비하여 유의적으로 감소하였다. 특히, $\mathrm{Ll}+\mathrm{Bh}$ 군은 $54.1 \pm 2.9 \mathrm{pg} / \mathrm{mL}$ 으로 infection군에 비하여 유의적으로 증가하였으며 면역 조절로 잘 알려진 $\mathrm{RG}$ 군과 비교하여도 유의적으로 증가된 $\mathrm{IL}-6$ 분비량을 감소시켰다. IL-10 측정 결과 바이러스 감염 이 안 된 $\mathrm{NC}$ 군은 $335.7 \pm 41.2 \mathrm{pg} / \mathrm{mL}$ 에서 infection군은 $2174.2 \pm 104.6 \mathrm{pg} / \mathrm{mL}$ 으로 증식능이 유의적으로 크게 증가 하는 하였는데 $\mathrm{Ll}+\mathrm{Bh}$ 군은 $578.5 \pm 67.358 .2 \pm 1.6 \mathrm{pg} / \mathrm{mL}$ 을 보여 infection군에 비하여 유의적으로 크게 낮추었으며 면 역조절로 잘 알려진 $\mathrm{RG}$ 군과 비교하여도 유의적으로 $\mathrm{IL}-10$ 분비량을 감소시키는 것으로 나타났다.

\section{면역 글로블린의 분비량 측정}

$\mathrm{HIV}$ 감염과 B 세포와의 관련성 연구에 의하면, $\mathrm{HIV}$ 의 감염에 의하여 B 세포의 교체가 상승하여 형질세포의 생존 기간이 짧아지게 되어져 불필요한 혈중 면역글로불린이 증가하게 된다고 밝혔다. $\mathrm{HIV}$ 가 B 세포의 $\mathrm{CD} 21$ 단백질의 감소를 시킴으로써 $\mathrm{B}$ 세포의 정상적인 기능을 하지 못하게 방해하는 것으로 밝혀져 있다(30). 실험기간 10 주 동안 $\beta$ -1,3/1,6-glucan, 유산균, $\beta-1,3 / 1,6$-glucan+유산균이 LP-BM5 murine AIDS virus에 감염된 면역 결핍동물 모델의 면역글 로불린 분비량 측정 결과는 Fig. 5 에 나타내었다. $\mathrm{IgE}$ 측정 결과 바이러스 감염이 안 된 $\mathrm{NC}$ 군에서 $0.89 \pm 0.04 \mathrm{ng} / \mathrm{mL}$ 으 로 바이러스 infection군에서는 $7.56 \pm 1.3 \mathrm{ng} / \mathrm{mL}$ 으로 증식능 이 유의적으로 증가하였다. 식이를 섭취한 모든 군은 infection군에 비하여 유의적으로 감소하였다. 특히, $\mathrm{Ll}$ 군, $\mathrm{Ll}+\mathrm{BL}$ 군, $\mathrm{Ll}+\mathrm{Bh}$ 군은 각각 $1.72 \pm 0.31,1.34 \pm 0.45,1.21 \pm 0.49$ $\mathrm{ng} / \mathrm{mL}$ 을 보여 infection군에 비하여 유의적으로 감소하였으 며 면역조절로 잘 알려진 $\mathrm{RG}$ 군 $(4.23 \pm 0.67 \mathrm{ng} / \mathrm{mL})$ 과 비교하 여도 유의적으로 $\mathrm{IgE}$ 분비량을 감소시켰다. $\mathrm{IgA}$ 측정 결과 바이러스 감염이 안 된 $\mathrm{NC}$ 군은 $3.73 \pm 0.36 \mathrm{ng} / \mathrm{mL}$ 에서 바이 러스에 infection군은 $9.38 \pm 0.84 \mathrm{ng} / \mathrm{mL}$ 으로 증식능이 유의 적으로 증가하였으며, 식이를 섭취한 모든 군은 infection군 에 비하여 유의적으로 감소하는 경향을 나타내었다. 특히, $\mathrm{Ll}$ 군, $\mathrm{Ll}+\mathrm{BL}$ 군, $\mathrm{Ll}+\mathrm{Bh}$ 군은 각각 $5.21 \pm 0.64,4.04 \pm 0.21$, $2.03 \pm 0.20 \mathrm{ng} / \mathrm{mL}$ 으로 infection군에 비하여 유의적으로 감 소하였으며 면역조절로 잘 알려진 $\mathrm{RG}$ 군과 비교하여도 유 의적으로 증가된 IgA분비량을 감소시키는 것으로 나타내 었다. $\mathrm{IgG}$ 측정 결과 바이러스 감염이 안 된 $\mathrm{NC}$ 군에서 $11.2 \pm 1.1 \mathrm{ng} / \mathrm{mL}$ 이었는데 바이러스 infection군에서 $91.1 \pm 0.63 \mathrm{ng} / \mathrm{mL}$ 으로 크게 증가하였는데 모든 군에서 낮아 졌으며 특히 $\mathrm{Ll}+\mathrm{Bh}$ 군에서 $19.1 \pm 0.8 \mathrm{ng} / \mathrm{mL}$ 으로 증식능이 유의적으로 크게 낮아지는 것을 확인하였다.

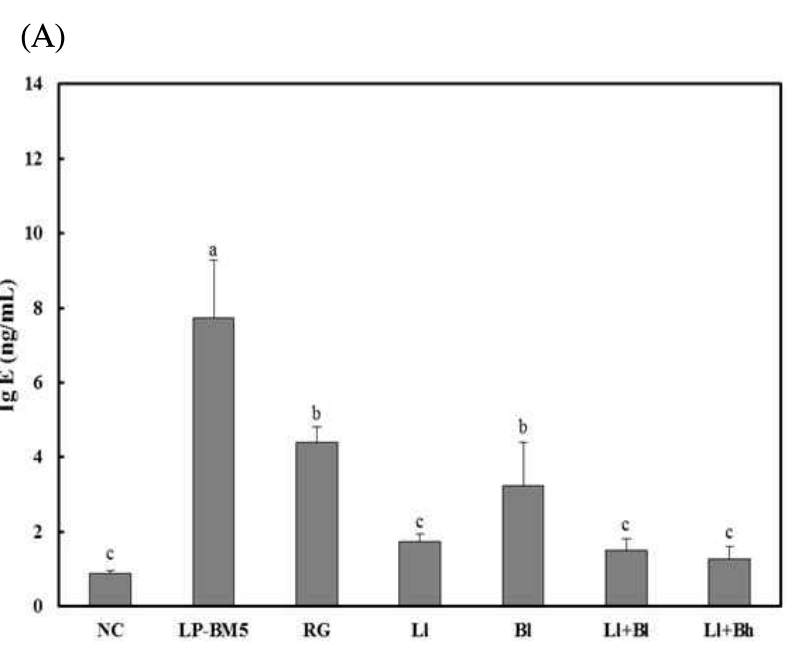

(B)

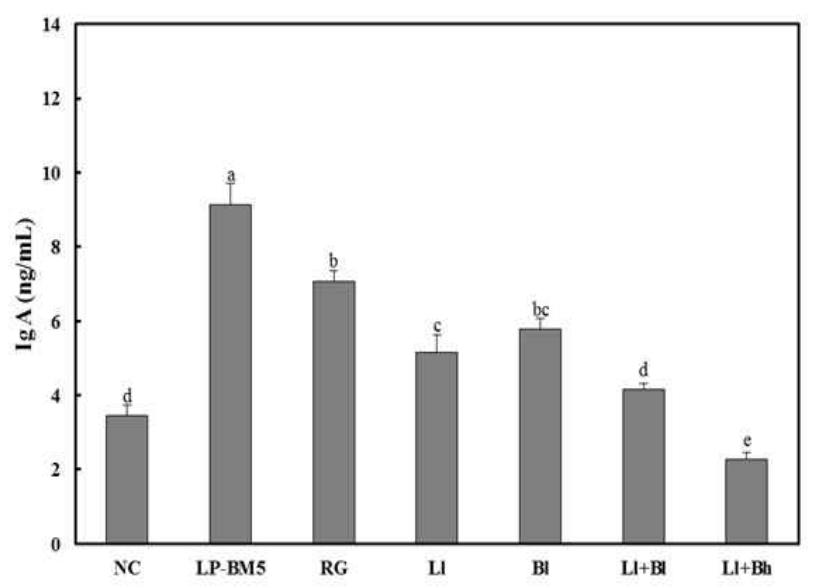

(C)

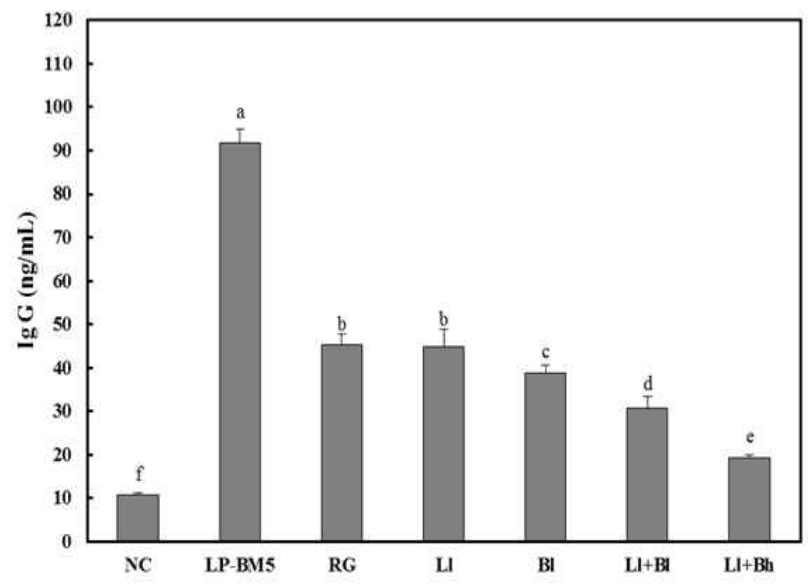

Fig. 5. Effect of $\beta$-glucan and Lactobacillus on Immunoglobulin $\mathrm{E}$ from serum in C87BL/6 mice with or without LP-BM5 virus.

A, Immunoglobulin E; B, Immunoglobulin A; C, Immunoglobulin G.

Values are presented as means \pm SD. Different letters show a significantly difference at $\mathrm{p}<0.05$ as determined by Duncan's multiple range test.

NC, non infection; LP-BM5, LP-BM5 virus infection; RG, LP-BM5 virus infection+Red Ginseng $200 \mathrm{mg} / \mathrm{kg}$ B.W; Ll, LP-BM5 virus infection+Lactobacillus $1 \times 10^{9}$ CFU $/ \mathrm{kg} \mathrm{B.W}$; Bl, LP-BM5 virus infection+ $\beta$-1,3/1,6-glucan $200 \mathrm{mg} / \mathrm{kg} \mathrm{B.W}$; Ll+Bl, LP-BM5 virus infection+Lactobacillus $1 \times 10^{9}$ CFU/kg B.W and $\beta-1,3 / 1,6$-glucan $200 \mathrm{mg} / \mathrm{kg} \mathrm{B.W}$; Ll+Bh, LP-BM5 virus infection+Lactobacillus $1 \times 10^{9}$ CFU/kg B.W and $\beta-1,3 / 1,6$-glucan 500 $\mathrm{mg} / \mathrm{kg}$ B.W. 


\section{요 약}

본 연구에서는 LP-BM5 murine AIDS virus에 감염된 면 역 결핍동물 모델을 이용하여 실험기간 10 주 동안 $\beta$ -1,3/1,6-glucan, 유산균 및 $\beta-1,3 / 1,6$-glucan+유산균의 식이 가 면역활성에 미치는 영향을 조사하였다. 그 결과 LP-BM5 murine AIDS virus에 감염으로 면역능이 떨어진 $\mathrm{T}$ 세포 증식 능은 홍삼대조군과 비교하여도 유의적으로 감소된 $\mathrm{T}$ 세포 증식능을 증가시키는 것으로 나타났고, $\mathrm{B}$ 세포 증식능은 감염 대조군에 비하여 유의적으로 증가된 B 세포 증식능을 감소되었다. cytokine 생성능에서는 Th1 type cytokine중에 서 $\mathrm{IL}-2, \mathrm{IL}-12, \mathrm{IL}-15$ 는 감염대조군에 비하여 분비량을 증 가시키는 것을 확인할 수 있었고, IFN- $\gamma$ 는 유산균과 $\beta$ -1,3/1,6-glucan을 각각 처리군이 혼합처리군보다 증식능이 증가하였다. TNF- $a$ 는 감염대조군에 비하여 유의적으로 감 소하였다. Th2 cytokine 들의 분비량 측정에서 IL-4, IL-6, IL-10 측정 결과 감염대조군에서 유의적으로 억제되어 Th1/Th2 type cytokine 발현을 조절하여 면역항상성을 유지 하는 것으로 보였다. 면역글로블린 분비량측정에서 $\mathrm{IgE}$, $\operatorname{IgA}, \operatorname{IgG}$ 모두 감염대조군에 비하여 유의적으로 떨어지는 것으로 나타났다. 이로서LP-BM5 murine AIDS virus에 감 염된 면역 결핍동물 모델에 $\beta-1,3 / 1,6$-glucan+유산균군을 혼합처리로 면역조절의 효능이 있음을 확인할 수 있었다.

\section{감사의 글}

본 연구는 농림축산식품부 고부가가치식품기술개발사 업(과제번호: 11407-3)에 의해 이루어진 것이며, 이에 감사 드립니다.

\section{References}

1. Tomasi TB Jr, Tan EM, Solomon A, Prendergast RA (1965) Characteristics of an immune system common to certain external secretions. J Exp Med, 121, 101-124

2. Gonzalez-Rey E, Chorny A, Delgado M (2007) Regulation of immune tolerance by anti-inflammatory neuropeptides. Nat Rev Immunol, 7, 52-63

3. Kim JS (2001) Mechanism of aging and prevention. Immune Network, 1, 104-108

4. KHSA (2016) Health functional food market trends and consumer survey. Korea Health Supplements Association. Seongnam, Korea, p 142-144

5. McIntosh M, Stone BA, Stanisich VA (2005) Curdlan and other bacterial $(1 \rightarrow 3)-\beta-D-g l u c a n s . ~ A p p l$ Microbiol
Biotechnol, 68, 163-173

6. Cui SW, Wang Q (2009) Cell wall polysaccharides in cereals: chemical structures and functional properties. Struct Chem, 20, 291-297

7. Matse AM, Knott ER, Teunissen PGM, Bartels PV (2000) Effects of high isostatic pressure on mushrooms. J Food Eng, 45, 11-6

8. Kimura Y, Sumiyoshi M, Suzuki T, Sakanaka, M (2006) Antitumor and antimetastatic activity of a novel water-soluble low molecular weight $\beta-1,3-\mathrm{D}$-glucan (branch $\beta-1,6$ ) isolated from Aureobasidium pullulans 1A1 strain black yeast. Anticancer Res, 26, 4131-4141

9. Brown GD, Gordon S (2005) Immune recognition of fungal $\beta$ glucans. Cell Microbiol, 7, 471-479

10. Brown GD (2006) Dectin-1: a signalling non-TLR pattern-recognition receptor. Nat Rev Immunol, 6, 33-43

11. Lee DH, Kim HW (2014) Innate immunity induced by fungal $\beta$-glucans via dectin-1 signaling pathway. Int J Med Mushrooms, 16, 1-16

12. Brown GD, Taylor PR, Reid DM, Willment JA, Williams, DL, Martinez-Pomares L, Wong SYC, Gordon S (2002) Dectin-1 is a major $\beta$-glucan receptor on macrophages. J Exp Med, 196, 407-412

13. Furrie E (2005) Probiotics and allergy. Proc Nutr Soc, 64, 465-469

14. Park HS, Lee SH, Uhm TB (1998) Selection of microorganisms for probiotics and their characterization. J Korean Soc Food Sci Nutr, 27, 433-440

15. Rather IA, Bajpai VK, Kumar S, Lim JH, Paek WK, Park YH (2016) Probiotics and Atopic Dermatitis: An Overview. Front Microbiol. 7, 1-7

16. Laiho K, Hoppu U, Ouwehand AC, Salminen S, Isolauri E (2002) Probiotics: on-going research on atopic individuals. Br J Nutr, 88, S19-S27

17. Kim HJ, Kim YJ, Lee SH, Yu J, Jeong SK, Hong SJ (2014) Effects of Lactobacillus rhamnosus on allergic march model by suppressing Th2, Th17, and TSLP responses via $\mathrm{CD} 4^{(+)} \mathrm{CD} 25^{(+)} \mathrm{Foxp}^{(+)}$Tregs. Clin immunol, 153, 178-186

18. Yoon JY, Hwang KT (2016) An in vitro study of immune activity by $\beta-1,3 / 1,6$-glucan isolated from Aureobasidium pullulans. Korean J Food Preserv, 23, 906-912

19. Lee SJ, Ahn KH, Park CS, Yoon BD, Kim MS (2009) Analysis of $\beta-(1 \rightarrow 3)(1 \rightarrow 6)$-glucan produced by Aureobasidium pullulans IMS-822. Korean J Microbiol, 45, 63-68

20. W Oboshi, M Amakawa, R Kato (2014) Effects of $\beta$ 
-glucan and lactic acid bacteria on gut immune system. Jap J Med Technol, 63, 673-679

21. Iida R, Saito K, Yamada K, Basile AS, Sekikawa K, Takemura M, Fujii H, Wada H, Seishima M, Nabeshima $\mathrm{T}$ (2000) Suppression of neurocognitive damage in LP-BM5-infected mice with a targeted deletion of the TNF-a gene. FASEB J, 14, 1023-1031

22. Liang B, Wang JY, Watson RR (1996) Murine AIDS, a key to understanding retrovirus-induced immunodeficiency. Viral Immunol, 9, 225-239

23. Odeleye OE, Eskelson CD, Watson RR (1992) Changes in hepatic lipid composition after infection by LP-BM5 murine leukemia virus causing murine AIDS. Life Sci, 51, 129-134

24. Dimitrov DS, Norwood D, Stantchev TS, Feng Y, Xiao X, Broder CC (1999) A mechanism of resistance to HIV-1 entry: inefficient interactions of CXCR4 with CD4 and gp120 in macrophages. Virology, 259, 1-6

25. Moir S, Buckner CM, Ho J, Wang W, Chen J, Waldner AJ, Posada JG, Kardava L, O'Shea MA, Kottilil S, Chun TW, Proschan MA, Fauci AS (2010) B cells in early and chronic HIV infection: evidence for preservation of immune function associated with early initiation of antiretroviral therapy. Blood, 116, 5571-5579

26. Gougeon ML, Lecoeur H, Dulioust A, Enouf MG, Crouvoiser M, Goujard C, Debord T, Montagnier L
(1996) Programmed cell death in peripheral lymphocytes from HIV-infected persons: increased susceptibility to apoptosis of CD4 and CD8 T cells correlates with lymphocyte activation and with disease progression. $\mathrm{J}$ Immunol, 156, 3509-3520

27. Morris L, Binley JM, Clas BA, Bonhoeffer S, Astill TP, Kost R, Hurley A, Cao Y, Markowitz M, Ho DD, Moore JP (1998) HIV-1 antigen-specific and -nonspecific B cell responses are sensitive to combination antiretroviral therapy. J Exp Med, 188, 233-245

28. Meyaard L, Schuitemaker H, Miedema F (1993) T-cell dysfunction in HIV infection: anergy due to defective antigen- presenting cell function? Immunol Today, 14, 161-164

29. Zimmerli SC, Harari A, Cellerai C, Vallelian F, Bart PA, Pantaleo G (2005) HIV-1-specific IFN-8/IL-2 -secreting CD8 $\mathrm{T}$ cells support CD4-independent proliferation of HIV-1-specific CD8 T cells. PNAS, 102, 7239-7244

30. Moir S, Malaspina A, Li Y, Chun TW, Lowe T, Adelsberger J, Baseler M, Ehler LA, Liu S, Davey RT Jr, Mican JA, Fauci AS (2000) B cells of HIV-1-infected patients bind virions through $\mathrm{CD} 21$-complement interactions and transmit infectious virus to activated $\mathrm{T}$ cells. J Exp Med, 192, 637-645 